Journal of Advanced Research in Fluid Mechanics and Thermal Sciences

\title{
Void and Moisture Content of Fiber Reinforced Composites
}

\author{
Nurul Zuhairah Mahmud Zuhudi ${ }^{1,}{ }^{*}$, Afiq Faizul Zulkifli ${ }^{1}$, Muzafar Zulkifli², Ahmad Naim Ahmad \\ Yahaya $^{3}$, Nurhayati Mohd Nur ${ }^{1}$, Khairul Dahri Mohd Aris ${ }^{1}$ \\ 1 Aerospace Section, Universiti Kuala Lumpur Malaysian Institute of Aviation Technology (UniKL MIAT), Lot 2891, Jalan Jenderam Hulu, 43800, \\ Dengkil, Selangor, Malaysia \\ 2 Green Chemistry and Sustainable Cluster, Universiti Kuala Lumpur Malaysian Institute of Chemical and Bioengineering Technology, 78000 Alor \\ Gajah, Melaka, Malaysia \\ 3 Universiti Kuala Lumpur Malaysian Institute of Chemical and Bioengineering Technology, 78000 Alor Gajah, Melaka, Malaysia
}

\begin{tabular}{l} 
ARTICLE INFO $\quad$ ABSTRACT \\
\hline
\end{tabular}

\section{Article history:}

Received 29 June 2021

Received in revised form 3 August 2021

Accepted 3 August 2021

Available online 30 September 2021

\section{Keywords:}

Void; moisture content; pre-preg; natural fiber composites

\begin{abstract}
In this paper, a review of the void and moisture content studies of fiber reinforced composites for both, synthetic and natural based fibers are presented. The review summarized the research papers in which include experimental and theoretical works that related to the void and moisture content studies. In addition to that, this review paper highlighting a few research studies conducted in literature on the effects of the void and moisture on the mechanical performances of the composite. Few common measurement methods used for the void and moisture determination are discussed here. The aims of this review, mainly to capture the trend ranging from the recent five years back and summarize the various studies and to compare the most common method for the determination of the void and moisture content. This paper is providing a baseline in the selection of the methods for the future work of the author's work with regard to the reduction of the presence of voids and moisture occur during the impregnation process of pre-pregs and their fiber reinforced composites, especially when using natural-based fiber.
\end{abstract}

\section{Introduction}

Fiber reinforced composites (FRC) are widely used in lightweight structural applications by the reason of their superior mechanical properties and lightness. Synthetic fibers are extensively used to reinforce polymeric resins in the creation of composite materials due to their advantageous mechanical properties. In the automotive industry, they are also specifically used because composite materials give a higher strength-to-weight ratio. The widespread use of synthetic fiber, however, contributes to environmental and recycling concerns. Natural fibers, therefore, deliver less costly and sustainable fiber resources. Natural fiber reinforced composites (NFRC) are gaining wide popularity due to its potential to be an alternative and environment friendly option to the existing synthetic fiber composites. The advantages of NFRC over the manmade fiber composites are renewable,

\footnotetext{
* Corresponding author.

E-mail address: zuhairah@unikl.edu.my
}

https://doi.org/10.37934/arfmts.87.3.7893 
carbon neutral, comparable high mechanical properties, low cost and weight, recyclable, biodegradable and produce organic waste that can be used to generate electricity at the end of their life cycle. They have several benefits over the conventional composites in terms of the high strength, light-weight, high durability and water resistant, chemical resistant, electrical resistant, fire resistant and corrosion resistant properties. In many engineering applications with an extremely wide variety of properties, NRFCs are being used increasingly. Whether derived from plants, animals, or minerals, natural fibers are classified according to their origins. It has been reported that natural fibers been used in various application, such as packing, building, ship, and automotive due to extraordinary properties compared to other synthetic fibers [1]. Plant fibers include leaf fibers (pineapple, sisal, and abaca), core fibers (hemp, jute, and kenaf), grass and reed fibers (wheat, corn, and rice), seed fibers (cotton, kapok, and coir), bast fibers (flax, jute, hemp, ramie, and kenaf), and all other types (wood and roots) [2].

Somehow, manufacturing defects are one of the key variables that deviate from the expectations of the mechanical properties of NFRC. They are described as irregularities that cause the composite properties to deviate from requirements that have been designed. Defects can be classified, based on their location, into matrix, fiber, and interface defects. Fiber defects include fiber waviness and misalignment and broken fibers (due to fiber curving during manufacturing, friction in the textile machine), interface defects include initial fiber/matrix debonding and interlaminar delamination, and matrix defects include incomplete matrix cure, and voids. Voids refer as the regions unfilled with polymer and fibers, are one of the most significant defects [3]. Their significance is due to their considerable effect on a wide range of composite properties and mechanisms leading to failure as well as to their high formation probability in different manufacturing techniques. As a result of their importance, voids are by far the most studied manufacturing defect. Water and moisture absorption of natural fibers have multiple effects, in terms of their properties, morphology, chemical composition, and dimensional stability. The composites made with fibers taken from different relative humidity $(\mathrm{RH})$ environments are expected to behave differently. On the other hand, when the composites are made with dry fibers, these can also absorb moisture in various conditions of humidity. Furthermore, if the composites are immersed under water, their properties are likely to be degraded by absorbing water. Excessive water or moisture can result in the swelling of the fiber that could minimize the mechanical and dimensional properties of the composites as a result of the appearance of micro cracks at fiber-matrix space [4]. The results in the past study showed that the moisture content affected the mechanical properties of the composites. For example, the strength and elongation at break of the jute yarn decreased with a decrease in moisture content [5].

In this paper, a review on the void and moisture content studies of fiber reinforced composites for both, synthetic and natural based fibers are presented. The review summarized the research papers in which include experimental and theoretical works that related to the void and moisture content studies. In addition to that, this review paper highlighting a few research studies conducted in literature on the effects of the void and moisture on the mechanical performances of the composite. Few common measurement methods used for the void and moisture determination are discussed here. The aims of this review, mainly to capture the trend ranging from the recent five years back and summarize the various studies and also to compare and conclude the most common methods for the determination of the void and moisture content. This paper is mainly providing a baseline in the selection of the methods for the future work of the author's work with regard to the reduction of the presence of voids and moisture occur during the impregnation process of pre-pregs and their fiber reinforced composites, especially when using natural-based fiber. 


\section{Past Studies on Void Content Investigation}

Void also known as porosity is defined as defect that occurs during the manufacturing process and it may play significant role in the mechanical performance of composites. The void content and their morphology may influence the composite properties, especially for the structural laminate of composites, when their presence between the layers, in which randomly generated during processing could resulting in obvious stress concentrator. This situation may lead to the composite delamination and crack initiation before propagating towards laminate failure. Understanding the void formation is important to reduce the void content percentages and their morphology (i.e., shape and size).

The manufacturing processing conditions are one of the factors contributing to the presence of void contents, which then reduce the performance of the composite itself. For example, voids may form during compounding or melt-flow processing, or because of uneven shrinkage during the solidification phase due to thermal gradients (cooling). An increase in the cooling rate results in an increase in the void content of composites. The fiber volume fraction and fiber length in the composites also are the main factors for void or bubble formation. The probability of void formation increases when the composite having higher fiber content and length. Figure 1 shows the extensive work carried out by various researchers from 2015 to 2020, studied the presence of void contents in their composite, which have been fabricated using various processing methods.

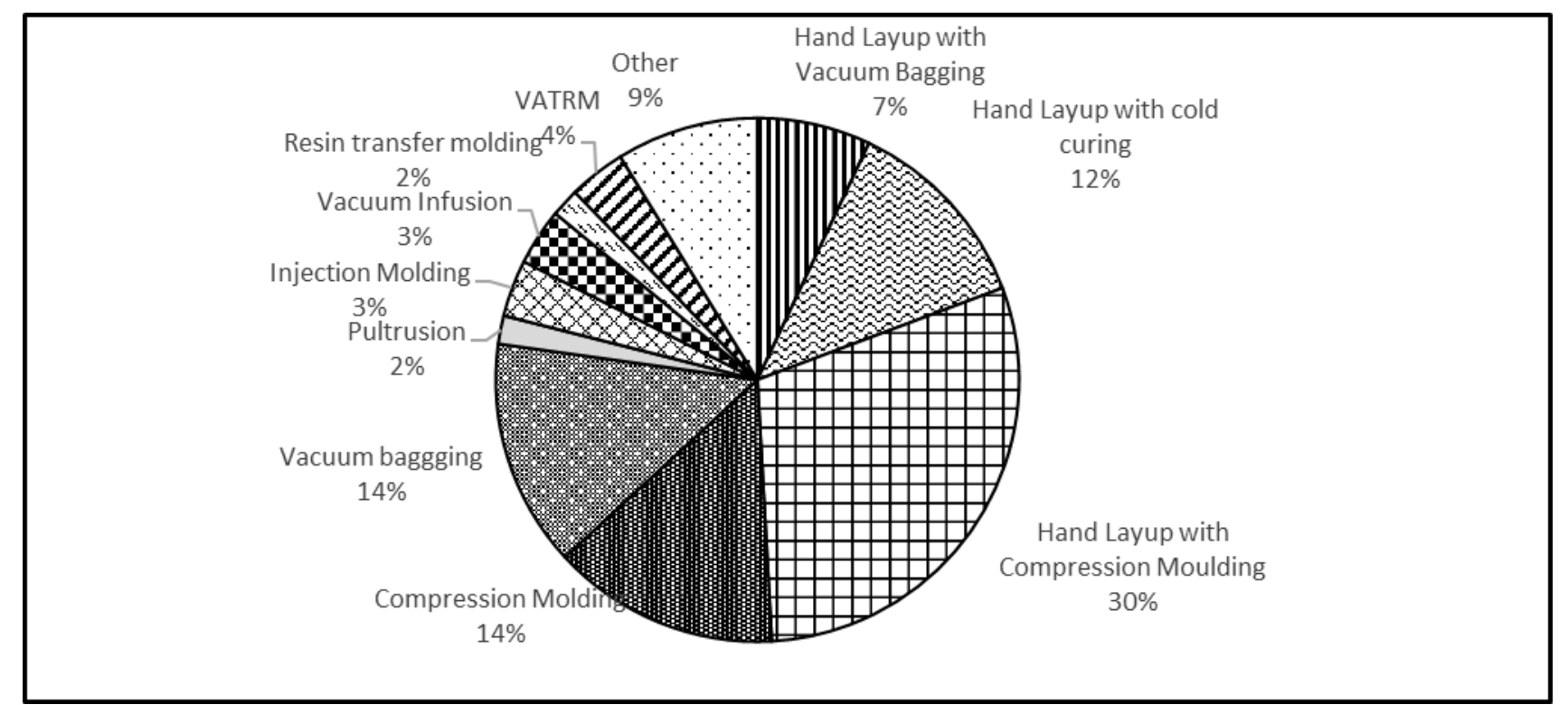

Fig. 1. Research papers on the study of void content of composites fabricated using various methods

In addition to the production technique and processing parameters, matrix material, moisture and solvent content, stacking sequence, and composite thickness are some of the factors that can affect the void content [6]. Air or other volatile compounds may be caught in the material during the incorporation of fiber into the matrix. Due to the fiber spacing and between the laminate and resinrich regions, micro voids can form in the composite along the individual fibers after curing, which has an adverse effect on the mechanical properties of the composites. Curing and cooling rate of the resin can also responsible for void formation [7].

Due towards the importance of the void characterisation, the void formation, characteristics and effects on mechanical properties in FRC have been extensively studied and summarized by various researchers [3]. They reported that, there are few types of the void morphology and characteristics, 
mainly the void types and their location of in the both unidirectional and woven-plies composites. In the studies with regard to woven fabric pre-preg and their composites, the main types observed in woven fabrics are (i) micro-void (intra-laminar void), with narrow and elongated shape in fiber direction inside tows, (ii) meso-void with the shape of irregular or spherical in resin-rich regions at tow intersections, i.e. at tow corners, (iii) flat void with pan-cake shape, occurs between the plies, i.e., between the overlying tows of two adjacent plies, and (iv) micro-void, with shape of small sphere exists usually in resin-rich regions.

In the reduction of the void content in the composite final products, the impregnation process and the evaporation of the volatiles are the key factors to be controlled, apart from the type of curing methods used for the composite manufacturing and their process parameters. The manufacturing technologies for composites using pre-pregs commonly with autoclave, Out of Autoclave (OoA) curing and automated pre-preg laying methods, in which the percentage of voids can be reduced mainly, by controlling the pressure and temperature. These issues have been addressed by various researchers as reported by Medhikhani et al., [3] in their extensive review. In the author's work, the schematic diagram of the void formation and their mechanism is carried out as can be seen from Figure 2 below, in understanding the void formation in the Out of Autoclave (OoA) process.

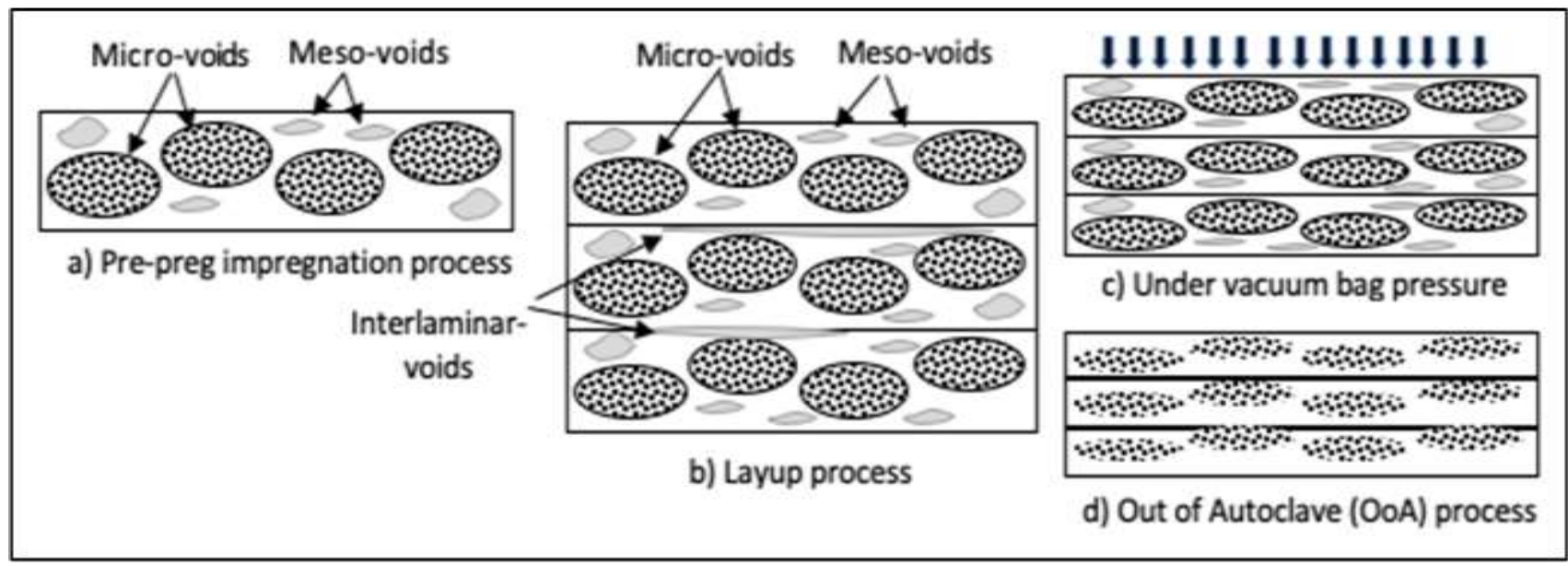

Fig. 2. The schematic diagram of woven fabric cross sectional area view with tows (a) The presence of void formation during pre-preg impregnation (b) Pre-preg layup process (Partially cured B-stage) (c) Pre-preg laminate under vacuum bagging and heat application using Out of Autoclave OoA process for the manufacturing of composites (d) Removal of voids after the Out of Autoclave (OoA) process, with the fully consolidated cured composite laminates

It is importance to extensively monitor the presence of voids in the pre-preg manufacturing and OoA process, therefore this review outlines a few techniques and methods for void content studies that has been summarized with regard to their advantages and disadvantages offered are shown in Table 1. There are few methods either using testing tools or set up of experiments in order to determine the void and using being used widely in various studies, mainly optical microscopy, scanning electron microscopy, microscopic computed tomography, ultrasonic testing or micro-CT and density determination. The methods used, are, either destructive or non-destructive, respectively. 
Table 1

A few techniques and methods for void studies and their advantages and disadvantages [3]

\begin{tabular}{|c|c|c|c|c|}
\hline Techniques & $\begin{array}{l}\text { Measurable } \\
\text { parameters }\end{array}$ & Advantages & Disadvantages & Reference \\
\hline $\begin{array}{l}\text { Density } \\
\text { determination }\end{array}$ & $\begin{array}{l}\text { - Void } \\
\text { content }\end{array}$ & $\begin{array}{l}\text { - Easy and } \\
\text { inexpensive } \\
\text { - Relatively quick }\end{array}$ & $\begin{array}{l}\text { - Accuracy dependence on input } \\
\text { properties } \\
\text { - Destructive } \\
\text { - Needing density input } \\
\text { - Providing nothing on other void } \\
\text { characteristics }\end{array}$ & [13-14] \\
\hline Microscopy & $\begin{array}{l}\text { - Void } \\
\text { content } \\
\text { - Size } \\
\text { - 2D shape } \\
\text { - Location } \\
\text { /distribution }\end{array}$ & $\begin{array}{l}\text { - Easy and } \\
\text { inexpensive } \\
\text { - Relatively quick } \\
\text { - Providing 2D } \\
\text { morphological } \\
\text { output }\end{array}$ & $\begin{array}{l}\text { - Section-biased } \\
\text { - Location-biased } \\
\text { - Needing multiple analysis } \\
\text { - Destructive }\end{array}$ & [9-15] \\
\hline $\begin{array}{l}\text { Ultrasonic } \\
\text { testing }\end{array}$ & $\begin{array}{l}\text { - Void } \\
\text { content } \\
\text { - Planar size } \\
\text { - Planar } \\
\text { location/ } \\
\text { distribution }\end{array}$ & $\begin{array}{l}\text { - Precise } \\
\text { - Non-destructive } \\
\text { - Possible for in- } \\
\text { service inspection } \\
\text { - Portable }\end{array}$ & $\begin{array}{l}\text { - Needing a coupling agent } \\
\text { (Improvement under progress) } \\
\text { - Only applicable to flat and } \\
\text { smooth surfaces } \\
\text { (Improvement under progress) } \\
\text { - Time consuming (improvement } \\
\text { under progress) } \\
\text { - Providing limited morphological } \\
\text { output }\end{array}$ & [16-18] \\
\hline Micro-CT & $\begin{array}{l}\text { - Void } \\
\text { content } \\
\text { - Size } \\
\text { - 3D shape } \\
\text {-Location } \\
\text { /distribution }\end{array}$ & $\begin{array}{l}\text { - Relatively accurate } \\
\text { - Providing full 3D } \\
\text { analysis } \\
\text { - Semi non- } \\
\text { destructive }\end{array}$ & $\begin{array}{l}\text { - Needing small samples } \\
\text { - Location-biased } \\
\text { - Time consuming } \\
\text { - Costly }\end{array}$ & [9-13-19] \\
\hline
\end{tabular}

Ultrasonic testing, with mature and standardized industrial testing apparatus and procedures, remains the main industrial instrument for assessing the void content and making a reject/accept decision. However, ultrasonic inspection does not provide precise information on the morphology of the void, the size of the individual voids (and the statistical distribution of these parameters), and the spatial distribution of the voids. Micro-CT is the most advanced and reliable, albeit costly, tool for accurate and detailed void observation and investigation. Methods for quantifying micro-CT images are emerging, but they are still an active subject of research and will likely mature in the next few years. High fidelity micro-CT is restricted to small-size specimens. There are various kinds of microscopes that can be used for imaging material cross-sections, such as optical and Scanning Electron Microscope (SEM). Commonly, the SEM method is widely used researchers to study the morphology especially for the study of fiber-matrix interfacial adhesion [8]. The most notable and critical difference between the two-microscopy images is the superior contrast between void and matter (fiber and matrix) of the SEM image in comparison with the optical image [9]. A study found that the value of void content measured through image analysis (performed on microscopy images of cross-sections) is higher than that obtained through the density determination technique [10].

Density testing technique that is popularly used by the researcher is a non-destructive and nonvisual technique that is able to calculate the overall void volume fraction within a specimen, providing accurate material properties and mass fraction values. The density of resin and composite can be measured through water buoyancy by Archimedes principle (ASTM D792), the density-gradient technique (ASTM D1505), and a direct measurement of weight and volume. The density of the fibers 
is to be measured through water buoyancy (for the fibers that absorb water). The matrix and fiber contents (weight and volume percentage) can be measured by the digestion or ignition of the matrix (ASTM D3171 and ASTM D2584) or by microscopy followed by image analysis methods. There are few researchers conducted analysis uses digital image processing, Matlab, and Microsoft Excel application to obtain the value of void fraction [11]. Accurate void content measurement requires accurate knowledge of the physical properties of the constituents, namely fiber and matrix. The most advanced and reliable, expensive, tool for precise and detailed observation and investigation of voids is micro-CT or also known as X-ray micro-CT. Micro CT technique is a nondestructive virtual slicing technique. Methods of quantification of the micro-CT images are emerging, but still are an active research subject and will probably be matured in the coming few years. High fidelity micro-CT is limited to specimens of small sizes [12]. With the capability to focus the X-ray beam to a-few micrometers spot size, $\mathrm{X}$-ray micro-CT emerges as the most accurate technique available for 3D evaluation of microscopic features, including voids inside FRCs. Still, the accuracy of the results depends largely on the image processing techniques that are employed for detection of voids. In some studies, synchrotron micro-CT is used for high-resolution analysis of voids [3].

With aim of reducing the void content percentages, in the various work related to the manufacturing of composites, most of them, emphasizing the measurement of the void content in their works. A tabulated summary of research papers investigated on the void content analysis using direct measurement method is shown in the Figure 3. It can be significantly observed that the most common direct measurement method to study void content is using Scanning Electron Microscopy (SEM), followed by the use of the Micro-computed tomography and linear optical microscopy and image analysis such as Image J software to estimate the void content percentages. Another method, which is using an Ultrasonic Scanning technique are getting less attention among the researchers. It may be due to the higher cost and more complicated preparation of samples, even though this method can be considered giving a comparable and reliable finding.

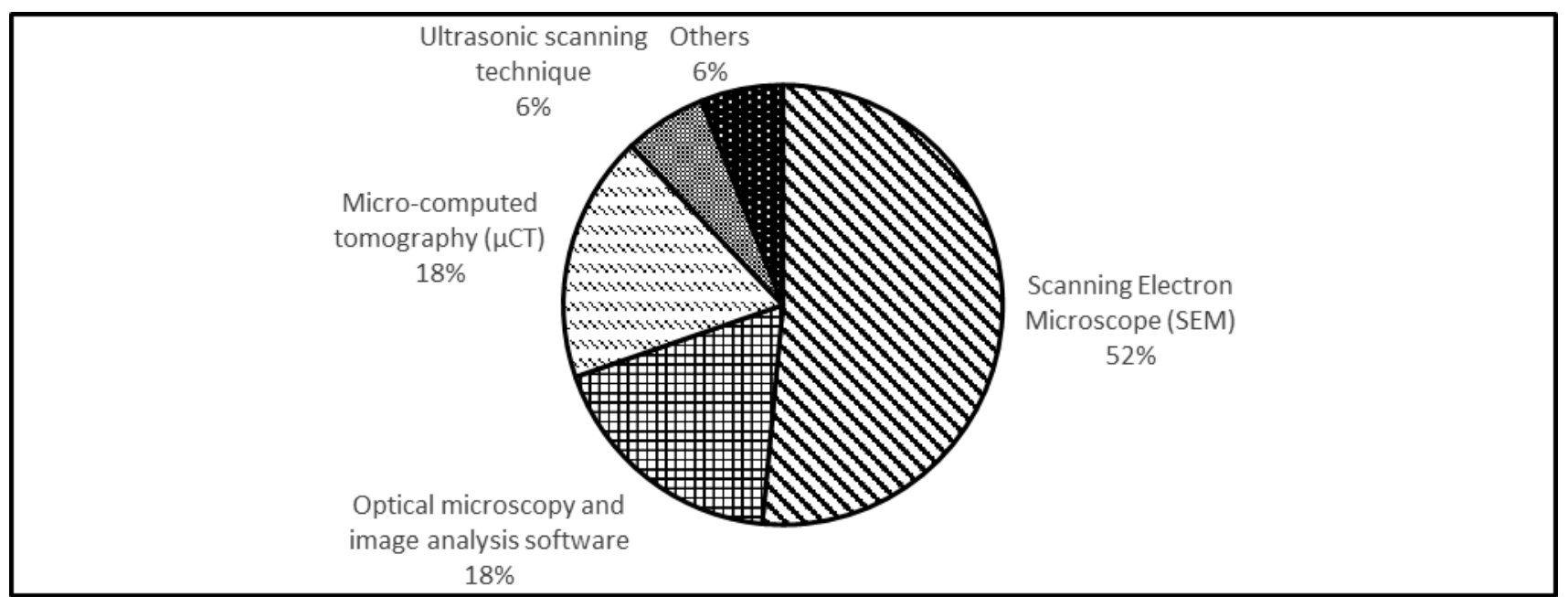

Fig. 3. Research papers on the study of void content of composites using various tools/methods [12-14-3744-47-68]

Apart of the direct measurement using the common tools/equipment of the experimental study, some of the researchers also conducted in direct measurement from the void content parameter to determine and estimate the void content percentage in the composites. A summary of research papers investigated on the void content studies using in direct measurement methods is shown in the Figure 4. It can be observed that most of the researchers are carried out the void measurement of the void content parameter such as void volume fractions and also density measurement, such as 
using ASTM 2734-70 and ASTM D3171. There are also very few studies such as conducted recently by Monticeli et al., [20]. using response surface methodology (RSM) equation, in evaluating the 3D void formation through a statistical approach such as ANOVA and Weibull model derived from the basic concept of void volume fraction measurement, with the aim of proposing a method to unveil the role of voids in fiber composite laminates manufactured via resin transfer molding [20].

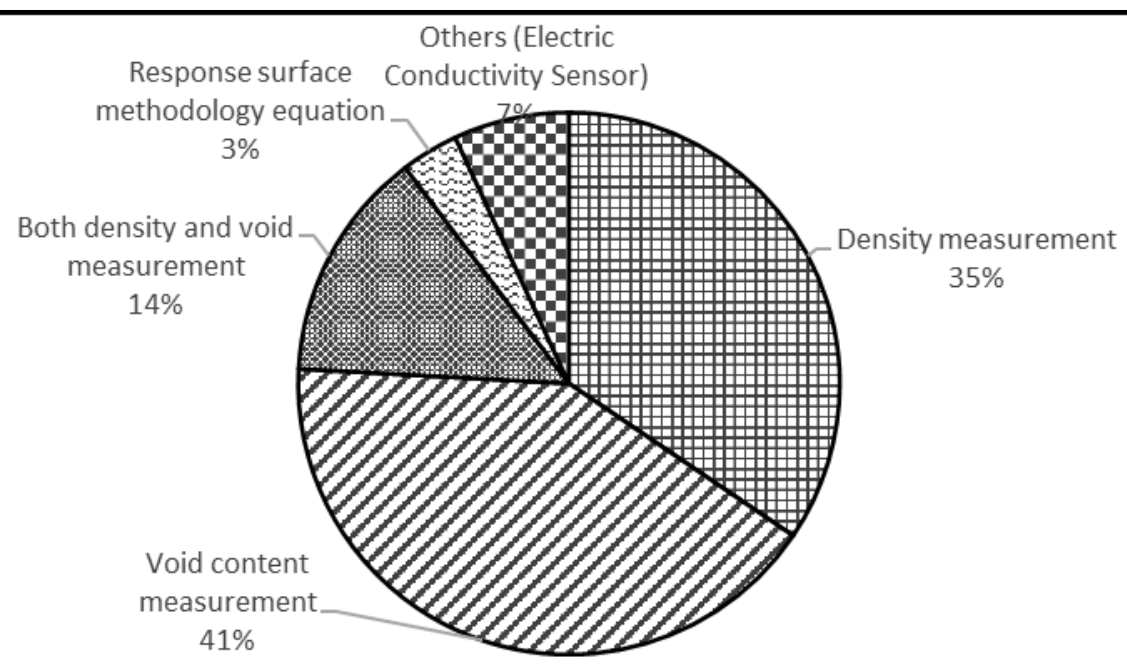

Fig. 4. Research papers on void content studies using the measurement (equation) of some parameters of the void content [14-20-30-37-52-58-62-64-69-82]

\section{Past Studies on Moisture Content Investigation}

Another important problem with NFRCs, besides void presence, is moisture content. The moisture existence further uptake led to degradation issues of composite laminates. Moisture content of materials is the amount of water contained in the systems that has significant effect on water absorption and fiber swelling behaviour [21]. As reported by Wandowski et al., [22] the moisture update could accelerate to reduce fatigue life, particularly on impacted laminates. Moisture is typically either characterized in terms of relative humidity in surrounding the specimen under investigation or specifically the moisture content (relative moisture mass) in the specimen itself. The moisture content offers a direct intrinsic measure of hygroscopic state of the material, although it is not always practical to quantify experimentally [23]. The presence of moisture influence that the fiber-matrix integrity for long-term performance of composites. Therefore, various experimental works, particularly related to natural-based fiber, also include the study on the measurement of moisture absorption behaviour.

With the presence of void formations in the OoA process, commonly in vacuum bagging process, which resulting from the processing stage shown in Figure 2, lead to the introduction of the moisture content in the composite systems. Apart from the air entrapment either inside tows or between plies during the vacuum bagging curing and OoA, moisture in the resin is another problem. The main volatiles within a pre-preg is water, with other volatiles such as alcohol, acetone, and ethanol. It is reported that if the water vapor pressure exceeds the hydrostatic resin pressure during cure, the moisture-rich voids can exist. Again, it is a need to control the moisture content in the pre-pregs, for example by having a conditioning procedure prior laying up and cure. The mechanism of the formation of moisture content during pre-preg impregnation and their vacuum bagging with OoA processes, affect the properties of the NRFCs is illustrated from Figure 5. Moisture absorption into the pre-pregs and their composites is by three main mechanisms: i) diffusion of water molecules 
through the micro-gaps between matrix chains; ii) capillary transport of water molecules into the gaps and flaws at the interface between the fibers and the matrices due to incomplete wetting and impregnation; and iii) transport of water molecules through micro-cracks in the matrix, formed during the fabrication process or arising from swelling fibers. After the fiber-matrix bonding is broken, the fibers fail to withstand the load adequately. The broken interface resulting and localizing matrix cracking. This cracking propagates and then lead to larger fiber fracture, delamination, or both. As the consequences, it may lower the mechanical properties of the NFRCs.

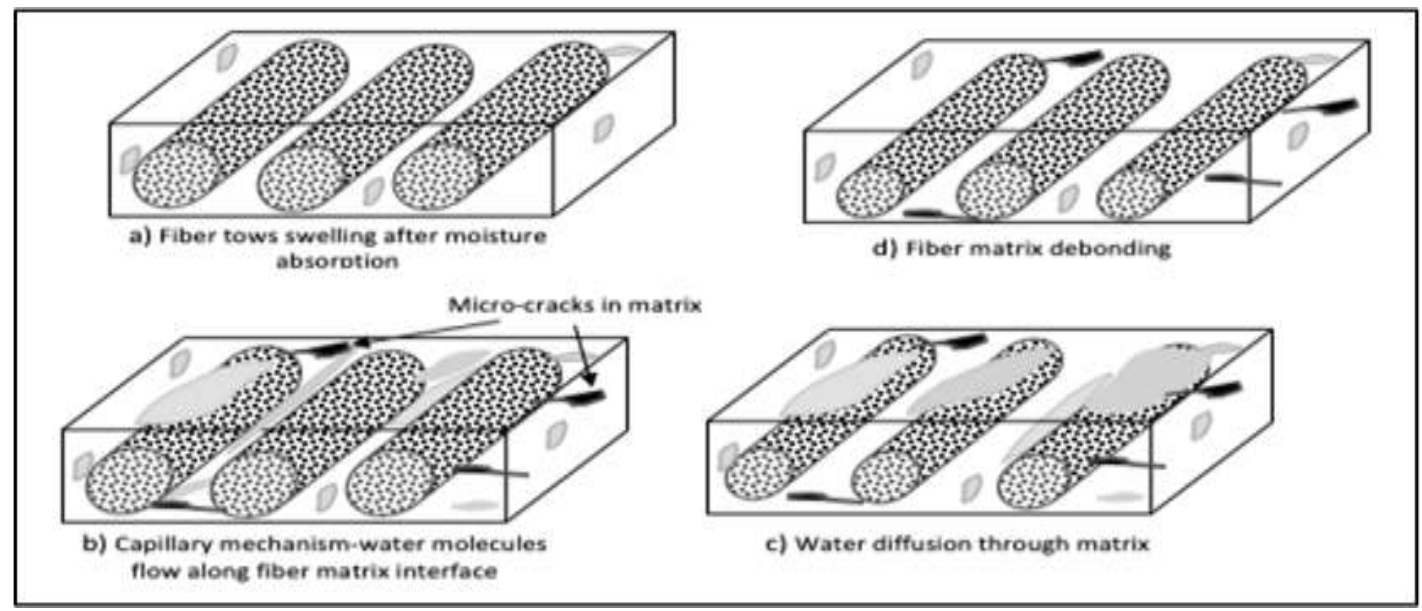

Fig. 5. Moisture content (plain grey in colour) mechanism during the pre-preg impregnation and Out of Autoclave (OoA) curing process

A summary of research papers investigated on the moisture content analysis studied on the common experimental moisture content studies using various tools or methods is shown in the Figure 6. It can be observed that the most common method is mainly from the measurement of the weight fraction and followed by drying oven method, that is a thermogravimetric method (loss on drying) in which the sample is dried for a period of time at constant temperature. The moisture content is determined by weighing the sample before and after drying. There are few improvised methods have been limitedly used to measure moisture absorption, namely as Electromechanical impedance (EMI) method [22] and Impedance spectroscopy [24]. Apart from that, there are few researchers used method with the determination by using absorbed moisture equation such as using ASTM D 5229/D 5229M, to measure moisture uptake, and also few works using Fick's diffusion laws.

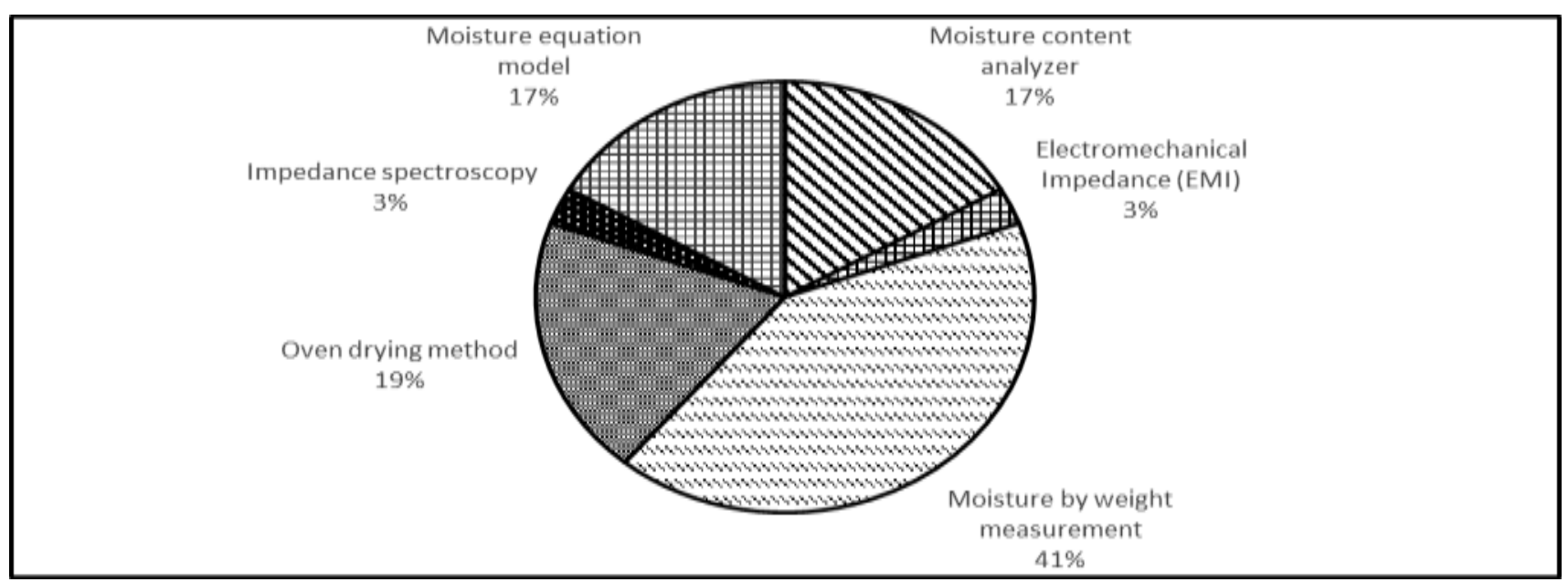

Fig. 6. Research papers studied on the common experimental moisture content studies using various tools or methods [5-22-24-29-33-41-71-81-83-106] 


\section{Effects of Void and Moisture Content on Mechanical Properties of Composites}

The properties of NFRC are different to each other according to previous studies, because of different kinds of fibers, sources, and moisture conditions. As reported, the performance of NFRC relies on some factors, like mechanical composition, micro-fibrillar angle, structure, defects, cell dimensions, physical properties, chemical properties, and also the interaction of a fiber with the matrix [25]. A tabulated summary of research studies conducted on effects of void and moisture contents on mechanical performance of composites is shown in Table 2. The reported research as shown in Table 2 obviously highlighting that the presence of void and moisture content in the fiber reinforced composite, mainly in NFRC, is a problematic issue which need to be addressed thoroughly.

\section{Table 2}

Research papers studied about the effect of moisture and void content studies on mechanical performances of composites

\begin{tabular}{|c|c|c|}
\hline Author (Year of Publication) & Type of fibers used & Mechanical Properties \\
\hline (Chaudhary, 2020) [29] & Jute, hemp, and flax/epoxy & $\begin{array}{l}\text { Hardness, Tensile testing, flexural testing and } \\
\text { morphological analysis }\end{array}$ \\
\hline (Karimzadeh, 2020) [30] & $\begin{array}{l}\text { Pineapple leaf fiber (PALF) } \\
\text { and glass fiber }\end{array}$ & Flexural and tensile properties \\
\hline (Binu Kumar, 2020) [31] & $\begin{array}{l}\text { Banana fiber and neem } \\
\text { fibers }\end{array}$ & Tensile strength \\
\hline (Venkatesha, 2020) [32] & $\begin{array}{l}\text { Bamboo and E-glass woven } \\
\text { fabric }\end{array}$ & Thickness swelling test, flexural and tensile test. \\
\hline (Moudood, 2019) [33] & Flax fiber & Tensile strength, modulus and strain at failure \\
\hline (Moudood, Rahman, 2019) [34] & Flax fiber & Mechanical testing and interfacial strength \\
\hline (Moudood, Hall, 2019) [33] & Flax fiber & Tensile properties and flexural modulus \\
\hline (Ouarhim, 2018) [35] & Few types of natural fibers & Static tensile and dynamic mechanical analysis \\
\hline (Kini, 2018) [36] & Glass fiber & Tensile and flexural properties \\
\hline (Di Landro, 2017) [14] & Carbon fiber & $\begin{array}{l}\text { Tensile and compressive tests, short beam shear } \\
\text { Tests (interlaminar strength) }\end{array}$ \\
\hline (Raghavendra, 2017) [37] & Jute fiber & Tensile and flexural properties \\
\hline (Liu, 2016) [38] & Carbon fiber & $\begin{array}{l}\text { Interlaminar shear strength (ILSS), compression } \\
\text { strength, fatigue strength and flexural strength }\end{array}$ \\
\hline (Chaichanawong, 2016) [39] & Glass fiber & $\begin{array}{l}\text { Tensile test, Flexural test \& microstructure } \\
\text { analysis }\end{array}$ \\
\hline $\begin{array}{l}\text { (Alzamora Guzman \& Brondsted, } \\
\text { 2015) [40] }\end{array}$ & Glass fiber & $\begin{array}{l}\text { Single-fiber tensile test, tension tests \& V-notch } \\
\text { shear tests }\end{array}$ \\
\hline (Munoz, 2015) [41] & Flax fiber & $\begin{array}{l}\text { Tensile test, flexural test and morphological } \\
\text { analysis }\end{array}$ \\
\hline (Berthet, 2015) [42] & Wheat straw fibers & Tensile properties \\
\hline$(\mathrm{Li}, 2015)[43]$ & Flax fiber & Tensile and interlaminar shear properties \\
\hline (Islam, 2014) [44] & Flax fabric & Tensile test, thermogravimetric analysis \\
\hline (Dong \& Takagi, 2014) [28] & Cellulose nanofibre & Flexural properties \\
\hline (Perez-Pacheco, 2013) [45] & Carbon fiber & $\begin{array}{l}\text { Acoustic emission ( } \mathrm{AE} \text { ) measurements } \& \text { tensile } \\
\text { testing }\end{array}$ \\
\hline (Hernandez Rueda, 2013) [46] & Carbon Fiber & $\begin{array}{l}\text { Interlaminar shear strength, low velocity impact } \\
\text { and plain compression }\end{array}$ \\
\hline
\end{tabular}


Various quantitative studies of the effect of voids and moistures on the mechanical properties of fiber/resin composites have been carried out and one of major findings as reported that, regardless of resin, fiber type, and fiber surface treatment, the interlaminar shear strength of a composite decreases about $7 \%$ for each $1 \%$ of void, respectively [26]. The void content in NFRC is a concern because of the voids inherent in natural fibers, which affect the transverse failure of the composites [27]. The studies also concluded that the stiffness or decrease in strength is a linear or second-order polynomial function of the void content. During the injection of the fibers into the resin, air or other volatile substances may be trapped within the composites and then, after curing the composites, micro-voids can form. These micro-voids create poor mechanical properties, which result in sudden failure of the composites. The shapes of the voids can be changed from spherical to elongated, and the void content can be decreased by a post-extrusion hot-drawing approach. An author assessed the effect of void content on the flexural properties of a vacuum-treated random-oriented wood pulp fiber/ starch composite manufactured using hot pressing [28]. Another significant finding from the review also showed that, the presence of voids may increase linearly with the different type of manufacturing processes to produce samples [19].

The characteristic of lignocellulose fibers as hydrophilic and moisture absorbing elements, leads to the presence of moisture in NFRCs. A large number of hydrogen bonds exist between the macromolecules in the cell wall of the plant fiber. The hydrogen bond breaks as moisture from the atmosphere comes into contact with the fiber, and hydroxyl groups form new hydrogen bonds with water molecules. The principal access to the penetrating water becomes the cross-section of the fiber. As a consequence, swelling within the matrix occurs when hydrophilic fiber is reinforced with hydrophobic resin fiber. This induces weak fiber-matrix bonding, dimensional instability, matrix cracking, and poor composite mechanical properties. Therefore, the removal or at least reduce the moisture from fibers is an essential step before and during the preparation of composites.

Currently, there is a common opinion that the mechanical properties of NFRC products are declining as the void and moisture content increases. Therefore, most of the void analysis studies published have concentrated on attempts to link the mechanical properties of NFRC products to the content of voids. It also should be noted here that it is far from sufficient to attempt to associate void content with some mechanical properties of NFRC products alone. It is quite clear that the processing parameters simultaneously influence the distribution, position, shape and size of the void during output. Each of these parameters has a different effect on NFRC products' mechanical properties. Therefore, the increasing trend of the studies on the fiber reinforced composite, are continuously being carried out in order to get the improvement with regards to their mechanical performance. This short review is intent to has a snapshot of the recent trend which showing this extensive attention given by researchers, world-widely, significantly not limited to the one as listed in this review.

\section{Conclusions}

As for the conclusion, a review on the void and moisture content studies of fiber reinforced composites for both, synthetic and natural based fibers has been presented. This review, has captured the trend ranging from the recent five years back and summarized the various studies. The most common method for the determination of the void and moisture content has been compared and concluded in providing a baseline in the selection of the methods for the future work of the author's work with regard to the reduction of the presence of voids and moisture occur during the impregnation process of pre-preg and their fiber reinforced composites, especially when using natural-based fiber. 


\section{Acknowledgement}

This research was funded by an internal grant, (STR 19029), Short Term Research Grant (STRG) from Universiti Kuala Lumpur.

\section{References}

[1] Yee, Koh Chai, Azwan Iskandar Azmi, Wan Azani Mustafa, Aiman Akmal Abdul Nasir, and Tan Chye. "Effect of Notch and Notch Size on the Flexural Performance of Flax Fibre Composites." Journal of Advanced Research in Applied Mechanics 52, (2020): 1-7.

[2] Lotfi, Amirhossein, Huaizhong Li, Dzung Viet Dao, and Gangadhara Prusty. "Natural fiber-reinforced composites: A review on material, manufacturing, and machinability." Journal of Thermoplastic Composite Materials 34, no. 2 (2021): 238-284. https://doi.org/10.1177/0892705719844546

[3] Mehdikhani, Mahoor, Larissa Gorbatikh, Ignaas Verpoest, and Stepan V. Lomov. "Voids in fiber-reinforced polymer composites: A review on their formation, characteristics, and effects on mechanical performance." Journal of Composite Materials 53, no. 12 (2019): 1579-1669. https://doi.org/10.1177/0021998318772152

[4] Dhakal, H. N., ZY and Zhang, and M. O. W. Richardson. "Effect of water absorption on the mechanical properties of hemp fibre reinforced unsaturated polyester composites." Composites science and technology 67, no. 7-8 (2007): 1674-1683. https://doi.org/10.1016/i.compscitech.2006.06.019

[5] Yu, Ying, Yuqiu Yang, Kazuo Tanabe, Mitsuo Mastuda, and Hiroyuki Hamada. "Effect of moisture content of jute fabric and hybridization structure on the impact properties of jute and jute/glass hybrid composites." Science and Engineering of Composite Materials 23, no. 4 (2016): 367-374. https://doi.org/10.1515/secm-2013-0147

[6] Zuhudi, Nurul Zuhairah Mahmud, Mulia Minhat, Mohd Hafizi Shamsuddin, Mohd Dali Isa, and Nurhayati Mohd Nur. "Optimum processing parameters for the fabrication of twill flax fabric-reinforced polypropylene (PP) composites." In AIP Conference Proceedings, vol. 1901, no. 1, p. 030002. AIP Publishing LLC, (2017). https://doi.org/10.1063/1.5010467

[7] Joseph, P. V. "Studies on short sisal fibre reinforced isotactic polypropylene composites." (2001).

[8] Supri, A. G., M. P. M. Hanif, and F. Zainuddin. "rHDPE/Wood Fiber Composites: Effect of Maleic Anhydride on Tensile Properties and Morphology Analysis". Journal of Advanced Research in Applied Mechanics 1 (2014):6-12.

[9] Little, John Eric, Xiaowen Yuan, and Mark lan Jones. "Characterisation of voids in fibre reinforced composite materials." NDT \& E International 46 (2012): 122-127. https://doi.org/10.1016/i.ndteint.2011.11.011

[10] Santulli, C., R. Garcia Gil, A. C. Long, and M. J. Clifford. "Void content measurements in commingled Eglass/polypropylene composites using image analysis from optical micrographs." Science and engineering of composite materials 10, no. 2 (2002): 77-90. https://doi.org/10.1515/SECM.2002.10.2.77

[11] Sukamta, Sukamta, Noviyanto Noviyanto, Sudarja Sudarja, and Sri Sundari. "Characteristics of Void Fraction Using Image Processing of Two-Phase Flow of Air-Pure Water and Glycerin (40-70\%) on A Transparent Mini Pipe with Slope of 450 to the Horizontal." Journal of Advanced Research in Experimental Fluid Mechanics and Heat Transfer 1 , no. 1 (2020): 29-37.

[12] Abdelal, Nisrin, and Steven L. Donaldson. "Comparison of methods for the characterization of voids in glass fiber composites." Journal of Composite Materials 52, $\quad$ no. $4 \quad$ (2018): $487-501$. https://doi.org/10.1177/0021998317710083

[13] Madra, Anna, Nemr El Hajj, and Malk Benzeggagh. "X-ray microtomography applications for quantitative and qualitative analysis of porosity in woven glass fiber reinforced thermoplastic." Composites Science and technology 95 (2014): 50-58. https://doi.org/10.1016/i.compscitech.2014.02.009

[14] Di Landro, Luca, Aurelio Montalto, Paolo Bettini, Stefania Guerra, Fabrizio Montagnoli, and Marco Rigamonti. "Detection of voids in carbon/epoxy laminates and their influence on mechanical properties." Polymers and Polymer Composites 25, no. 5 (2017): 371-380. https://doi.org/10.1177/096739111702500506

[15] Bodaghi, M., C. Cristóvão, R. Gomes, and N. C. Correia. "Experimental characterization of voids in high fibre volume fraction composites processed by high injection pressure RTM." Composites Part A: Applied Science and Manufacturing 82 (2016): 88-99. https://doi.org/10.1016/i.compositesa.2015.11.042

[16] Lin, L., X. Zhang, J. Chen, Y. F. Mu, and X. M. Li. "A morphology-dependent model applied to predict void content of composites based on ultrasonic attenuation coefficient: Random Void Model." Applied Physics A: Materials Science \& Processing 103, (2011): 1153-1157. https://doi.org/10.1007/s00339-010-6061-x

[17] Neuenschwander, Juerg, Roman Furrer, and Arno Roemmeler. "Application of air-coupled ultrasonics for the characterization of polymer and polymer-matrix composite samples." Polymer Testing 56 (2016): 379-386. https://doi.org/10.1016/i.polymertesting.2016.11.002 
[18] Karabutov, A. A., N. B. Podymova, and I. O. Belyaev. "The influence of porosity on ultrasound attenuation in carbon fiber reinforced plastic composites using the laser-ultrasound spectroscopy." Acoustical Physics 59, no. 6 (2013): 667-673. https://doi.org/10.1134/S1063771013060080

[19] Nikishkov, Yuri, Luca Airoldi, and Andrew Makeev. "Measurement of voids in composites by X-ray Computed Tomography." Composites Science $\quad$ and $\quad$ Technology $89 \quad 13$ (2013): https://doi.org/10.1016/i.compscitech.2013.09.019

[20] Monticeli, Francisco M., José Humberto S. Almeida Jr, Roberta M. Neves, Felipe G. Ornaghi, and Heitor L. Ornaghi. "On the 3D void formation of hybrid carbon/glass fiber composite laminates: A statistical approach." Composites $\begin{array}{lllllll}\text { Part A: } \quad \text { Applied } & \text { Science } & \text { (2020): } & 106036 .\end{array}$ https://doi.org/10.1016/i.compositesa.2020.106036

[21] Jumaidin, Ridhwan, Nur Wardah Adam, Rushdan Ahmad Ilyas, Mohamed Saiful Firdaus Hussin, Mastura Mohammad Taha, Muhd Ridzuan Mansor, Umar Al-Amani Azlan, and Mohd Shukri Yob. "Water transport and physical properties of sugarcane bagasse fibre reinforced thermoplastic potato starch biocomposite." Journal of Advanced Research in Fluid Mechanics and Thermal Sciences 61, no. 2 (2019): 273-281.

[22] Wandowski, T., P. Malinowski, L. Skarbek, and W. Ostachowicz. "Moisture detection in carbon fiber reinforced polymer composites using electromechanical impedance technique." Proceedings of the Institution of Mechanical Engineers, Part C: Journal of Mechanical Engineering Science 230, no. 2 (2016): 331-336. https://doi.org/10.1177/0954406215574239

[23] Gamstedt, E. Kristofer. "Moisture induced softening and swelling of natural cellulose fibres in composite applications." In IOP Conference Series: Materials Science and Engineering, vol. 139, no. 1, p. 012003 . IOP Publishing, 2016. https://doi.org/10.1088/1757-899X/139/1/012003

[24] Grammatikos, Sotirios A., Richard J. Ball, Mark Evernden, and Ryan G. Jones. "Impedance spectroscopy as a tool for moisture uptake monitoring in construction composites during service." Composites Part A: Applied Science and Manufacturing 105 (2018): 108-117. https://doi.org/10.1016/i.compositesa.2017.11.006

[25] Jauhari, Nitin, Raghvendra Mishra, and Harischchandra Thakur. "Natural fibre reinforced composite laminates-a review." Materials Today: Proceedings 2, no. 4-5 (2015): 2868-2877. https://doi.org/10.1016/i.matpr.2015.07.304

[26] Gholampour, Aliakbar, and Togay Ozbakkaloglu. "A review of natural fiber composites: Properties, modification and processing techniques, characterization, applications." Journal of Materials Science 55, no. 3 (2020): 829-892. https://doi.org/10.1007/s10853-019-03990-y

[27] Madsen, Bo, and Hans Lilholt. "Physical and mechanical properties of unidirectional plant fibre composites - an evaluation of the influence of porosity." Composites Science and Technology 63, no. 9 (2003): 1265-1272. https://doi.org/10.1016/S0266-3538(03)00097-6

[28] Dong, Chensong, and Hitoshi Takagi. "Flexural properties of cellulose nanofibre reinforced green $\begin{array}{llllll}\text { composites." Composites } & \text { Part } & \text { B: } & \text { Engineering } 58 & \text { (2014): } & 418-421 .\end{array}$ https://doi.org/10.1016/j.compositesb.2013.10.032

[29] Chaudhary, Vijay, Pramendra Kumar Bajpai, and Sachin Maheshwari. "Effect of moisture absorption on the mechanical performance of natural fiber reinforced woven hybrid bio-composites." Journal of Natural Fibers (2018). https://doi.org/10.1080/15440478.2018.1469451

[30] Karimzadeh, A., M. Y. Yahya, M. N. Abdullah, and K. J. Wong. "Effect of stacking sequence on mechanical properties and moisture absorption characteristic of hybrid PALF/glass fiber composites." Fibers and Polymers 21, no. 7 (2020): 1583-1593. https://doi.org/10.1007/s12221-020-9640-2

[31] Karimzadeh, A., M. Y. Yahya, M. N. Abdullah, and K. J. Wong. "Effect of stacking sequence on mechanical properties and moisture absorption characteristic of hybrid PALF/glass fiber composites." Fibers and Polymers 21 , no. 7 (2020): 1583-1593. https://doi.org/10.1007/s12221-020-9640-2

[32] Venkatesha, B. K., R. Saravanan, and K. Anand Babu. "Effect of moisture absorption on woven bamboo/glass fiber reinforced epoxy hybrid composites." Materials Today: Proceedings $45 \quad$ (2021): $216-221$. https://doi.org/10.1016/j.matpr.2020.10.421

[33] Moudood, Abdul, Wayne Hall, Andreas Öchsner, Huaizhong Li, Anisur Rahman, and Gaston Francucci. "Effect of moisture in flax fibres on the quality of their composites." Journal of Natural Fibers 16, no. 2 (2019): $209-224$. https://doi.org/10.1080/15440478.2017.1414651

[34] Moudood, Abdul, Anisur Rahman, Andreas Öchsner, Mainul Islam, and Gaston Francucci. "Flax fiber and its composites: An overview of water and moisture absorption impact on their performance." Journal of Reinforced Plastics and Composites 38, no. 7 (2019): 323-339. https://doi.org/10.1177/0731684418818893

[35] Ouarhim, Wafa, Nadia Zari, and Rachid Bouhfid. "Mechanical performance of natural fibers-based thermosetting composites." In Mechanical and physical testing of biocomposites, fibre-reinforced composites and hybrid composites, pp. 43-60. Woodhead Publishing, 2019. https://doi.org/10.1016/B978-0-08-102292-4.00003-5 
[36] Kini, U. Achutha, Manjunath Shettar, Sathyashankara Sharma, and Pavan Hiremath. "Behavioral study of mechanical properties of glass fiber-epoxy composites under moisture absorption." Int. J. Mech. Eng. Tech. 9 (2018): 01-05.

[37] Raghavendra, Gujjala, Kankanala Anil Kumar, Merum Harsha Kumar, Bhukya RaghuKumar, and Shakuntala Ojha. "Moisture absorption behavior and its effect on the mechanical properties of jute-reinforced epoxy composite." Polymer Composites 38, no. 3 (2017): 516-522. https://doi.org/10.1002/pc.23610

[38] Xueshu, L. I. U., and C. H. E. N. Fei. "A review of void formation and its effects on the mechanical performance of carbon fiber reinforced plastic." Engineering Transactions 64, no. 1 (2016): 33-51.

[39] Chaichanawong, Jintawat, Chanchai Thongchuea, and Surat Areerat. "Effect of moisture on the mechanical properties of glass fiber reinforced polyamide composites." Advanced Powder Technology 27, no. 3 (2016): 898902. https://doi.org/10.1016/i.apt.2016.02.006

[40] Guzman, V. Alzamora, and Povl Brøndsted. "Effects of moisture on glass fiber-reinforced polymer composites." Journal of Composite Materials 49, $\quad$ no. 8 (2015): $911-920$. https://doi.org/10.1177/0021998314527330

[41] Muñoz, Raybel, Jose A. Rodriguez, M. Elena Páez-Hernández, Irais Sánchez-Ortega, and Eva M. Santos. "Determination of lipoxygenase activity in cereals grains using a silver nanoparticles assay." Journal of Chemistry (2015). https://doi.org/10.1155/2015/390275

[42] Berthet, M-A., Nathalie Gontard, and H. Angellier-Coussy. "Impact of fibre moisture content on the structure/mechanical properties relationships of PHBV/wheat straw fibres biocomposites." Composites Science and Technology 117 (2015): 386-391. https://doi.org/10.1016/i.compscitech.2015.07.015

[43] Li, Yan, Qian Li, and Hao Ma. "The voids formation mechanisms and their effects on the mechanical properties of flax fiber reinforced epoxy composites." Composites Part A: Applied Science and Manufacturing 72 (2015): 40-48. https://doi.org/10.1016/i.compositesa.2015.01.029

[44] Islam, M. S., and M. Miao. "Optimising processing conditions of flax fabric reinforced Acrodur biocomposites." Journal of Composite Materials 48, no. $26 \quad$ (2014): 3281-3292. https://doi.org/10.1177/0021998313508995

[45] Pérez-Pacheco, E., J. I. Cauich-Cupul, A. Valadez-González, and P. J. Herrera-Franco. "Effect of moisture absorption on the mechanical behavior of carbon fiber/epoxy matrix composites." Journal of materials science 48, no. 5 (2013): 1873-1882. https://doi.org/10.1007/s10853-012-6947-4

[46] Rueda, Silvia Hernández. "Curing, defects and mechanical performance of fiber-reinforced composites." PhD diss., Universidad Politécnica de Madrid, 2013.

[47] Zainudin, Zuraidah, Noor Izyan Syazana Mohd Yusoff, Mat Uzir Wahit, and Siti Hajjar Che Man. "Mechanical, Thermal, Void Fraction and Water Absorption of Silane Surface Modified Silk Fiber Reinforced Epoxy Composites." Polymer-Plastics Technology and Materials 59, no. 18 (2020): 1987-2002. https://doi.org/10.1080/25740881.2020.1784215

[48] Hu, Wei, Timotei Centea, and Steven Nutt. "Effects of material and process parameters on void evolution in unidirectional prepreg during vacuum bag-only cure." Journal of Composite Materials 54, no. 5 (2020): 633-645. https://doi.org/10.1177/0021998319864420

[49] Umashankaran, M., S. Gopalakrishnan, and S. Sathish. "Preparation and characterization of tensile and bending properties of basalt-kenaf reinforced hybrid polymer composites." International Journal of Polymer Analysis and Characterization 25, no. 4 (2020): 227-237. https://doi.org/10.1080/1023666X.2020.1781480

[50] Farhang, Leyla, Mohammad Mohseni, Navid Zobeiry, and Göran Fernlund. "Experimental study of void evolution in partially impregnated prepregs." Journal of Composite Materials 54, no. 11 (2020): 1511-1523. https://doi.org/10.1177/0021998319883934

[51] Balaji, A., R. Purushothaman, R. Udhayasankar, S. Vijayaraj, and B. Karthikeyan. "Study on mechanical, thermal and morphological properties of banana fiber-reinforced epoxy composites." Journal of Bio-and Tribo-Corrosion 6, no. 2 (2020): 1-10. https://doi.org/10.1007/s40735-020-00357-8

[52] Ismail, Ahmad Safwan, Mohammad Jawaid, and Jesuarockiam Naveen. "Void content, tensile, vibration and acoustic properties of kenaf/bamboo fiber reinforced epoxy hybrid composites." Materials 12, no. 13 (2019): 2094. https://doi.org/10.3390/ma12132094

[53] Acharya, Samir Kumar, and Subhrajit Pradhan. "Study of mechanical behaviour of Eulaliopsis binata fiber reinforced $\begin{array}{lllll}\text { polymer } \quad \text { composite." Materials } \quad \text { Today: } & \text { Proceedings } 19 & \text { (2019): }\end{array}$ https://doi.org/10.1016/j.matpr.2019.07.610

[54] Bruni-Bossio, Brianna M., Garrett W. Melenka, Cagri Ayranci, and Jason P. Carey. "Micro-computed tomography analysis of natural fiber and bio-matrix tubular-braided composites." Journal of Composite Materials 53, no. 28-30 (2019): 4003-4013. https://doi.org/10.1177/0021998319853023 
[55] Neto, J. S. S., R. A. A. Lima, D. K. K. Cavalcanti, J. P. B. Souza, R. A. A. Aguiar, and M. D. Banea. "Effect of chemical treatment on the thermal properties of hybrid natural fiber-reinforced composites." Journal of Applied Polymer Science 136, no. 10 (2019): 47154. https://doi.org/10.1002/app.47154

[56] Bhuvaneshwaran, M., P. S. Sampath, and Suresh Sagadevan. "Influence of fiber length, fiber content and alkali treatment on mechanical properties of natural fiber-reinforced epoxy composites." Polimery 64 (2019). https://doi.org/10.14314/polimery.2019.2.2

[57] Melenka, Garrett W., Brianna M. Bruni-Bossio, Cagri Ayranci, and Jason P. Carey. "Examination of voids and geometry of bio-based braided composite structures." In IOP Conference Series: Materials Science and Engineering, vol. 406, no. 1, p. 012012. IOP Publishing, 2018. https://doi.org/10.1088/1757-899X/406/1/012012

[58] Swain, Priyadarshi Tapas Ranjan, Sankar Narayan Das, and Shakti Prakash Jena. "Manufacturing and study of thermo-mechanical behaviour of surface modified date palm leaf/glass fiber reinforced hybrid composite." Materials Today: $\quad$ Proceedings 5, $\quad$ no. $9 \quad$ (2018): $18332-18341$. https://doi.org/10.1016/i.matpr.2018.06.172

[59] Oliver-Ortega, Helena, M. F. Llop, Francesc Xavier Espinach, Quim Tarrés, M. Ardanuy, and P. Mutjé. "Study of the flexural modulus of lignocellulosic fibers reinforced bio-based polyamide11 green composites." Composites Part B: Engineering 152 (2018): 126-132. https://doi.org/10.1016/i.compositesb.2018.07.001

[60] Kalyana Sundaram, S., S. Jayabal, N. S. Balaji, and G. Bharathiraja. "Study of chemical and mechanical properties of Dharbai fiber reinforced polyester composites." Advanced Composite Materials 27, no. 1 (2018): $107-117$. https://doi.org/10.1080/09243046.2017.1394667

[61] Ivey, Marcus, Garrett W. Melenka, Jason P. Carey, and Cagri Ayranci. "Characterizing short-fiber-reinforced composites produced using additive manufacturing." Advanced Manufacturing: Polymer \& Composites Science 3, no. 3 (2017): 81-91. https://doi.org/10.1080/20550340.2017.1341125

[62] MR, Sanjay, and B. Yogesha. "Study on water absorption behaviour of jute and kenaf fabric reinforced epoxy composites: hybridization effect of e-glass fabric." Inter J Compos Mater 6 (2016): 55-62.

[63] Helmus, Rhena, James Kratz, Kevin Potter, Pascal Hubert, and Roland Hinterhölzl. "An experimental technique to characterize interply void formation in unidirectional prepregs." Journal of Composite Materials 51, no. 5 (2017): 579-591. https://doi.org/10.1177/0021998316650273

[64] Amiri, Ali, and Chad A. Ulven. "Advanced method for void fraction evaluation of natural fiber composites using micro-Ct technology." In SAMPE Conference Proceedings. 2016.

[65] Liebig, Wilfried V., Karl Schulte, and Bodo Fiedler. "Hierarchical analysis of the degradation of fibre-reinforced polymers under the presence of void imperfections." Philosophical transactions of the Royal Society A: Mathematical, physical and engineering sciences 374, no. $2071 \quad$ (2016): 20150279. https://doi.org/10.1098/rsta.2015.0279

[66] Kern, William T., Wonsuk Kim, Alan Argento, Ellen C. Lee, and Deborah F. Mielewski. "Finite element analysis and microscopy of natural fiber composites containing microcellular voids." Materials \& Design 106 (2016): $285-294$. https://doi.org/10.1016/i.matdes.2016.05.094

[67] Protz, Richard, Nils Kosmann, Maik Gude, Werner Hufenbach, Karl Schulte, and Bodo Fiedler. "Voids and their effect on the strain rate dependent material properties and fatigue behaviour of non-crimp fabric composites materials." Composites Part $\quad$ B: $\quad$ Engineering $83 \quad$ (2015): https://doi.org/10.1016/j.compositesb.2015.08.018

[68] Jayamani, Elammaran, Sinin Hamdan, Muhammad Khusairy Bin Bakri, Soon Kok Heng, Md Rezaur Rahman, and Akshay Kakar. "Analysis of natural fiber polymer composites: Effects of alkaline treatment on sound absorption." Journal of Reinforced Plastics and Composites 35, no. 9 (2016): $703-711$. https://doi.org/10.1177/0731684415620046

[69] Amirkhosravi, Mehrad, Maya Pishvar, Youssef K. Hamidi, and M. Cengiz Altan. "Accurate characterization of fiber and void volume fractions of natural fiber composites by pyrolysis in a nitrogen atmosphere." In AIP Conference Proceedings, vol. 2205, no. 1, p. 020032. AIP Publishing LLC, 2020. https://doi.org/10.1063/1.5142947

[70] Zakaria, K. Z., H. M. Akil, M. S. M. Shamsuddin, and ZA Mohd Ishak. "Mechanical performance of pultruded kenaf/glass hybrid fiber reinforced unsaturated polyester under hygrothermal conditions." In AIP Conference Proceedings, vol. 2267, no. 1, p. 020045. AIP Publishing LLC, 2020. https://doi.org/10.1063/5.0016407

[71] Fiore, V., C. Sanfilippo, and L. Calabrese. "Influence of sodium bicarbonate treatment on the aging resistance of natural fiber reinforced polymer composites under marine environment." Polymer Testing 80 (2019): 106100. https://doi.org/10.1016/j.polymertesting.2019.106100

[72] Refiadi, Gunawan, Yusi Syamsiar, and Hermawan Judawisastra. "The Tensile Strength of Petung Bamboo Fiber Reinforced Epoxy Composites: The Effects of Alkali Treatment, Composites Manufacturing, and Water Absorption." In IOP Conference Series: Materials Science and Engineering, vol. 547, no. 1, p. 012043. IOP Publishing, 2019. https://doi.org/10.1088/1757-899X/547/1/012043 
[73] Kumar, Sandeep, V. K. Patel, K. K. S. Mer, Brijesh Gangil, Tej Singh, and Gusztáv Fekete. "Himalayan natural fiberreinforced epoxy composites: effect of Grewia optiva/Bauhinia Vahlii fibers on physico-mechanical and dry sliding wear behavior." Journal of Natural Fibers (2019). https://doi.org/10.1080/15440478.2019.1612814

[74] Kumar, Sandeep, Krishan Kant Singh Mer, Brijesh Gangil, and Vinay Kumar Patel. "Synergy of rice-husk filler on physico-mechanical and tribological properties of hybrid Bauhinia-vahlii/sisal fiber reinforced epoxy composites." Journal of Materials Research and technology 8, no. 2 (2019): 2070-2082. https://doi.org/10.1016/i.jmrt.2018.12.021

[75] Patel, Ammar, Shekar Mekala, Oleksandr G. Kravchenko, Talha Yilmaz, Dian Yuan, Liang Yue, Richard A. Gross, and Ica Manas-Zloczower. "Design and formulation of a completely biobased epoxy structural adhesive." ACS Sustainable Chemistry \& Engineering 7, no. $19 \quad$ (2019): 16382-16391. https://doi.org/10.1021/acssuschemeng.9b03489

[76] Sanjay, M. R., and B. Yogesha. "Studies on hybridization effect of jute/kenaf/E-glass woven fabric epoxy composites for potential applications: Effect of laminate stacking sequences." Journal of Industrial Textiles 47, no. 7 (2018): 1830-1848. https://doi.org/10.1177/1528083717710713

[77] Das, Geetanjali, and Sandhayarani Biswas. "Effect of fiber parameters on physical, mechanical and water absorption behaviour of coir fiber-epoxy composites." Journal of Reinforced Plastics and Composites 35, no. 8 (2016): 644653. https://doi.org/10.1177/0731684415626594

[78] Sanjay, M. R., G. R. Arpitha, L. Laxmana Naik, K. Gopalakrishna, and B. Yogesh. "Studies on mechanical properties of banana/e-glass fabrics reinforced polyester hybrid composites." Journal of Material and Environmental Science 7, no. 9 (2016): 3179-3192.

[79] Sharba, Mohaiman Jaffar, Suhad D. Salman, Zulkiflle Leman, Mohamed TH Sultan, Mohamad R. Ishak, and Mohammad A. Azmah Hanim. "Effects of processing method, moisture content, and resin system on physical and mechanical properties of woven kenaf plant fiber composites." BioResources 11, no. 1 (2016): 1466-1476. https://doi.org/10.15376/biores.11.1.1448-1465

[80] Mahesha, G. T., S. B. Satish, K. M. Vijaya, and K. Subrahmanya Bhat. "Preparation of unidirectional grewia serrulata fiber-reinforced polyester composites and evaluation of tensile and flexural properties." Journal of natural fibers 13, no. 5 (2016): 547-554. https://doi.org/10.1080/15440478.2015.1081575

[81] Anderson, J. P., and M. C. Altan. "Formation of voids in composite laminates: Coupled effect of moisture content and processing pressure." Polymer Composites 36, no. 2 (2015): 376-384. https://doi.org/10.1002/pc.22952

[82] Gueroult, Sébastien, Aurélie Lebel-Lavacry, Chung Hae Park, Laurent Bizet, Abdelghani Saouab, and Joël Bréard. "Analytical modeling and in situ measurement of void formation in liquid composite molding processes." Advanced Composite Materials 23, no. 1 (2014): 31-42. https://doi.org/10.1080/09243046.2013.862383

[83] Santhanam, V., R. Dhanaraj, M. Chandrasekaran, N. Venkateshwaran, and S. Baskar. "Experimental investigation on the mechanical properties of woven hybrid fiber reinforced epoxy composite." Materials Today: Proceedings 37 (2021): 1850-1853. https://doi.org/10.1016/j.matpr.2020.07.444

[84] Syaqira, S., N. Shamsudin, Z. Leman, S. M. Sapuan, T. T. Dele-Afolabi, and Azmah Hanim. "Tensile Strength and Moisture Absorption of Sugar Palm-Polyvinyl Butyral Laminated Composites." Polymers 12, no. 9 (2020): 1923. https://doi.org/10.3390/polym12091923

[85] Moudood, Abdul, Anisur Rahman, Nayeem Md Lutful Huq, Andreas Öchsner, Md Mainul Islam, and Gaston Francucci. "Mechanical properties of flax fiber-reinforced composites at different relative humidities: Experimental, geometric, and displacement potential function approaches." Polymer Composites 41, no. 12 (2020): 4963-4973. https://doi.org/10.1002/pc.25766

[86] liang Wang, Quan, Sheng ling Xiao, and Sheldon Q. Shi. "Natural fiber-metallic composites with remarkable gradient structures." Materials $\quad$ Today $\quad$ Communications $25 \quad 101453$. https://doi.org/10.1016/i.mtcomm.2020.101453

[87] Mishra, Chandrakanta, Chitta Ranjan Deo, and Smitismita Baskey. "Influence of moisture absorption on mechanical properties of kenaf/glass reinforced polyester hybrid composite." Materials Today: Proceedings 38 (2021): 25962600. https://doi.org/10.1016/i.matpr.2020.08.100

[88] Khan, Anish, R. Vijay, D. Lenin Singaravelu, M. R. Sanjay, Suchart Siengchin, Francis Verpoort, Khalid A. Alamry, and Abdullah M. Asiri. "Extraction and characterization of natural fiber from eleusine indica grass as reinforcement of sustainable fiber-reinforced polymer composites." Journal of Natural Fibers (2019): 1-9. https://doi.org/10.1080/15440478.2019.1697993

[89] Manimaran, P., P. Senthamaraikannan, M. R. Sanjay, M. K. Marichelvam, and Mohammad Jawaid. "Study on characterization of Furcraea foetida new natural fiber as composite reinforcement for lightweight applications." Carbohydrate polymers 181 (2018): 650-658. https://doi.org/10.1016/i.carbpol.2017.11.099 
[90] Lila, Manish Kumar, Brijendra Singh, Bahadur Singh Pabla, and Inderdeep Singh. "Effect of environmental conditioning on natural fiber reinforced epoxy composites." Materials today: proceedings 5, no. 9 (2018): 1700617011. https://doi.org/10.1016/i.matpr.2018.04.105

[91] Maslinda, A. B., and Abdul Majid. "MS; Ridzuan, MJM; Afendi, M.; Gibson, AG Effect of water absorption on the mechanical properties of hybrid interwoven cellulosic-cellulosic fibre reinforced epoxy composites." Compos. Struct 167 (2017): 227-237. https://doi.org/10.1016/i.compstruct.2017.02.023

[92] Mizera, Cestmir, David Herak, Petr Hrabe, and Abraham Kabutey. "Effect of temperature and moisture content on tensile behaviour of false banana fibre (Ensete ventricosum)." International Agrophysics 31, no. 3 (2017): 377. https://doi.org/10.1515/intag-2016-0067

[93] Rajeshkumar, G., V. Hariharan, and T. P. Sathishkumar. "Characterization of Phoenix sp. natural fiber as potential reinforcement of polymer composites." Journal of Industrial Textiles 46, no. 3 (2016): 667-683. https://doi.org/10.1177/1528083715591581

[94] Xia, Changlei, Kaili Wang, Youming Dong, Shifeng Zhang, Sheldon Q. Shi, Liping Cai, Han Ren, Hualiang Zhang, and Jianzhang Li. "Dual-functional natural-fiber reinforced composites by incorporating magnetite." Composites Part B: Engineering 93 (2016): 221-228. https://doi.org/10.1016/i.compositesb.2016.03.016

[95] Codispoti, Rosamaria, Daniel V. Oliveira, Renato S. Olivito, Paulo B. Lourenço, and Raul Fangueiro. "Mechanical performance of natural fiber-reinforced composites for the strengthening of masonry." Composites Part B: Engineering 77 (2015): 74-83. https://doi.org/10.1016/i.compositesb.2015.03.021

[96] Agarwal, Rakshit, M. Ramachandran, and Stanly Jones Retnam. "Tensile properties of reinforced plastic material composites with natural fiber and filler material." ARPN Journal of Engineering and Applied Sciences 10, no. 5 (2015): 2217-2220.

[97] Bayatpour, Afshin, and Mehdi Hojjati. "Moisture Effect on Properties of Out-of-Autoclave Laminates with Different Void Content." International Journal of Composite Materials 10, no. 1 (2020): 1-9.

[98] Raghu, M. J., and Govardhan Goud. "Effect of surface treatment on mechanical properties of Calotropis procera natural fiber reinforced epoxy polymer composites." In AIP Conference Proceedings, vol. 2274, no. 1, p. 030031. AIP Publishing LLC, 2020. https://doi.org/10.1063/5.0022584

[99] Guloglu, Gorkem E., and M. Cengiz Altan. "Moisture absorption of carbon/epoxy nanocomposites." Journal of Composites Science 4, no. 1 (2020): 21. https://doi.org/10.3390/ics4010021

[100] Mishra, Chandrakanta, Chitta Ranjan Deo, and Smitismita Baskey. "Influence of moisture absorption on mechanical properties of kenaf/glass reinforced polyester hybrid composite." Materials Today: Proceedings 38 (2021): 25962600. https://doi.org/10.1016/i.matpr.2020.08.100

[101] Zhang, Yan, Qiuhui Ling, Xueting Lu, Qun Fang, and Fangli Sun. "Rheology, morphological evolution, thermal, and mechanical properties of epoxy modified with polysulfone and cellulose nanofibers." Journal of Applied Polymer Science 137, no. 18 (2020): 48628. https://doi.org/10.1002/app.48628

[102] Ryvolová, Martina. "The Effect of Moisture on the Mechanical Properties of Flax Prepreg." In PROCEEDING OF 7TH INTERNATIONAL CONFERENCE ON TRENDS IN AGRICULTURAL ENGINEERING 2019. Czech University of Life Sciences, 2019.

[103] Wu, Yingji, Changlei Xia, Liping Cai, Andres C. Garcia, and Sheldon Q. Shi. "Development of natural fiber-reinforced composite with comparable mechanical properties and reduced energy consumption and environmental impacts for replacing automotive glass-fiber sheet molding compound." Journal of Cleaner Production 184 (2018): $92-100$. https://doi.org/10.1016/i.jclepro.2018.02.257

[104] Chilali, Abderrazak, Mustapha Assarar, Wajdi Zouari, Hocine Kebir, and Rezak Ayad. "Analysis of the hydromechanical behaviour of flax fibre-reinforced composites: Assessment of hygroscopic expansion and its impact on internal stress." Composite Structures 206 (2018): 177-184. https://doi.org/10.1016/i.compstruct.2018.08.037

[105] Meenalochani, K. S., and BG Vijayasimha Reddy. "A review on water absorption behavior and its effect on mechanical properties of natural fibre reinforced composites." Int. J. Innovat. Res. Adv. Eng 4 (2017): 143-147.

[106] Shrivastava, Rahul, Amit Telang, R. S. Rana, and Rajesh Purohit. "Mechanical properties of Coir/G Lass fiber epoxy resin hybrid composite." Materials Today: Proceedings 4, no. 2 (2017): 3477-3483. https://doi.org/10.1016/i.matpr.2017.02.237 